\title{
References to Kurds in Medieval Arabic and Persian Literature
}

\author{
Mustafa Dehqan \\ Karadj, Iran
}

\begin{abstract}
While studies of the Kurds usually concentrate on principal Kurdish materials, much less attention has been paid to the Kurdish community and its related topics as reflected in non-Kurdish sources. Until recently, the Kurds were known often from Kurdish literature and a very few non-Kurdish historical works, mostly difficult of access. This article presents the most important references to Kurds in Arabic and Persian sources, from the viewpoint of medieval historians, scientists, poets, sheikhs, diplomats, et cetera; sometimes from that of the Kurds themselves, only not in the Kurdish language. The element common to all these notes is the attempt to make parallel use of sources from different types which complement each other: it is very interesting to compare and contrast them with regard to various historical topics concerning the other communities in the Middle East.
\end{abstract}

Keywords: al-Kurd, al-Kurdiya, al-Akrad, Kurdistan, Kurds, Kurdish, Arabic, Persian, Medieval.

\section{Introduction}

This article deals with the history and religion of the Kurds, the 'mountain people' of the Middle East, as they were imagined by the 
Arabs and Persians. It is a bibliographical study based on Arabic and Persian traditions, which include many important entries on the Kurds, and it is the purpose of this article to address these references to Kurdish society, as far as possible in a historical context. ${ }^{1}$

Medieval Arabic and Persian references to the Kurds are not easy to find, although anyone wishing to research medieval Kurdish history needs to know about them, especially where to find them, and the literary genres to which they belong. The texts that preserve specifically Kurdish references are certainly not limited to sources in Arabic and Persian characters, but can also be written in other languages and alphabets. The following medieval Arabic and Persian sources, for their part, are not confined to specifically Kurdish references but also contain references to Armenian, Georgian, Turkish, and other communities which, while not specifically Kurdish, were an integral part of the universe of medieval Kurdistan. What we mean here by texts preserving Kurdish references are those that take account of Kurdish religion, Kurdish sheikhs, Kurdish history and culture, and Kurdish tribes. To be Kurdish means to belong to a separate community, distinguished in these sources from Persians, Arabs or Turks.

All the historical sources on which my notes are based are published. These publications include the complete editions of the referenced Arabic and Persian texts. Nearly all the books listed in this article have been examined and were acquired, copied or consulted in libraries over a period of two years. My aim in this article is not just to address subject matter on Kurds, but also to arouse interest in the problems, ideas and arguments current in the medieval Kurdish world - many of which have never been considered. I very much hope that readers of the article will wish to go on to read the references themselves. I have tried to bring out something of the range of Kurdish culture by following a number of central references from their origins in history, to their discussion in literature, without attempting in any way to provide a comprehensive account of the period and its main writers. There already exist a number of books that

1 My research was sponsored by Iran's National Science Foundation. I owe warm thanks to Professor Akihiko Yamaguchi of Tokyo University for sparing time amid many other tasks to read the whole work in draft. 
describe in some detail the cultural milieu in which history and literature developed in the medieval Middle East. The emphasis in this article is however on the references themselves and on the location and study of the hitherto unknown Kurdish information to be found in Arabic and Persian sources.

In transliterating the Arabic and Persian texts I have followed the transliteration used in The Encyclopaedia of Islam. There are minor discrepancies, but these should not prove a stumbling block to the researcher. In the transcription of proper names, I must plead guilty to wild inconsistency. Although I have been guided by cataloguers' and publishers' spellings, it was difficult to adhere consistently to these.

The main entries are authors' own references to titles, terms, chapters, and topics. All of these are written in italics. Page numbers refer to the pages of the primary sources, and not to editors' introductions or notes. An asterisk denotes that the transcription of a word is doubtful.

\section{1. al-Farāhīdī, Abī 'Abd al-Raḥmān al-Khalīl b. Aḷmad}

(Lived in the eighth century C.E.)

Kitāb al-'Ayn (ed. M. al-Makhzūmī and I. al-Sāmarrā̄i); language: Arabic; subject: dictionary.

See vol. 5, under bäb al-käf wa al-dāl wa al-ra' ma'ahumā, p. 326.

\section{Bashshār b. Burd, Abū Mu'ādh}

(Born ca. 714-5 C.E.)

D̄̄wān (ed. S. al-Hawwārī), language: Arabic; subject: poem in Arabic.

See vol. 2, under 'Aqaba b. Salam, p. 233.

Ibid., cf. vol. 4, under Abī Muslim al-Khurāsän̄̄, p. 43.

\section{3. al-Balādhurī, Aḥmad b. Yahỵā b. Jābir b. Dāwūd}

(Lived in the ninth century C.E.)

Futūh al-Buldān (ed. Tahqīq al-Turāth), language: Arabic; subject: history.

See under futüh Armīnìya, p. 199 and 202.

Ibid. under fath Hamadhān, p. 303. 
Ibid. under fath Qazwin, p. 315.

Ibid. fath Kawr al-Ahwäz, p. 371.

\section{4. al-Jāḥiz, Abū 'Uthmān 'Amr b. Baḥr al-Fuqaymī al-Bașrī}

(Lived from ca. 776 to 869 C.E.)

Kitāb al-Hayawān (ed. 'A. M. Hārūn), language: Arabic; subject: $a d a b$ literature.

See vol. 1, under akhlāq al-khasĭ, p. 136.

Idem, al-Bayān wa al-Tabȳ̄n (ed. 'A. Būmulham), language: Arabic; subject: $a d a b$ literature.

Cf. vol. 1, under Bashr b. al-Mu'tamir yuqanninu ușull al-bilägha, p. 130.

Ibid., cf. vol. 3, under manāfi' al-'așā wa muräfiquhā, p. 35.

Idem, al-Bukhalā (ed. 'A.'Abd al-Sātir), language: Arabic; subject: $a d a b$ literature.

Cf. under Khälid b. Yazìd, p. 76.

Idem, Kitäb al-Bighāl (ed. 'A. Būmulham), language: Arabic; subject: adab literature.

Cf. under bäb al-khalq al-murakkab, p. 70.

\section{5. al-Andalusī, Ahmad b. Muhammad b. 'Abd Rabuh}

(Lived in the ninth century C.E.)

al-'Iqd al-Farìd (ed. Tahqīq al-Turāth), language: Arabic; subject: miscellaneous.

See vol. 5, under al-musta'īn, p. 103.

Ibid., cf. vol. 6, under tibā' al-insān wa sā'ir al-hayawān, p. 246.

\section{6. al-Ṭabarī, Abū Ja'far Muḥammad b. Jarīr b. Yazīd} (Died in 923 C.E.)

Mukhtașar Ta'rīkh al-Rusul wa al-Mulūk wa al-Khulafä' (ed. N. alJarrāh), language: Arabic; subject: history.

See vol. 1, under raja'a al-hadìth ila hadīth b. Ishāq , p. 80.

Ibid., cf. under al-khabar 'an mulük al-Furs, p. 229.

Ibid., cf. under Malik Kasrā Abarwīz, p. 282.

Cf. vol. 2, under khabar Salama b. al-Ashja' $\breve{\imath}$ wa al-Akräd, p. 735. 
Cf. vol. 3, under dhikr al-sabab alladhī kān...'Abd al-Malik b. Marwän, pp. 1229 and 1231.

Cf. vol. 6, under dhikr al-khabar' 'an...wa al-sabab fihä, p. 2077.

Ibid., cf. under dhikr al-khabar 'an...al-sa'lül, pp. 2082-2083.

Ibid., cf. under dhikr al-khabar...ilayhā, p. 2092.

Ibid., cf. under khabar waqa'a Akrād Dārbān ma'a Șăhib al-Zanj, p. 2093.

Ibid., cf. under dhikr al-khabar 'an sabab Abī Ahmad, p. 2102.

Ibid., cf. under khabar al-waqa'a bayn al-Akrād wa al-A'räb, p. 2149.

Ibid., cf. under al-khabar 'ammä käna fihā min al-ahdāth, p. 2189.

\section{7. $\operatorname{Mas}^{6} \overline{\mathbf{u}} \mathrm{i}$, Abu al-Hiasan 'Alī b. al-Ḥusayn}

(Born ca. 893-896 C.E.)

Murüj al-Dhahab wa Ma'ädin al-Jawhar fi Tuhaf al-Ashräf min alMulūk wa Ahl al-Dirāyāt (ed. Q. al-Shamā'ī al-Rafā'î̀), language: Arabic; subject: history.

See vol. 1, under dhikr mä ishtamil..., p. 21.

Cf. vol. 2, under 'illa suknā al-badaw, p. 133.

Ibid., cf. under al-Akrād wa nasabuhum wa masākinuhum, pp. 134135.

Ibid. Cf. vol. 3, under maqtal al-Mukhtār, p. 101.

Ibid. Cf. vol. 4, under khurūj al-Shārī bi al-Yaman, p. 129.

Idem, al-Tanbīh wa al-Ishräf (ed. Taḥīq al-Turāth), language: Arabic; subject: history.

Cf. under dhikr al-awwal minhā wa huwa al-Habashī, p. 64.

Ibid., cf. under dhikr al-tabaqa al-thānīya, pp. 94-95.

\section{8. al-Mutanabbī, Abu al-Ṭayyib Ạ̣mad b. al-Ḥusayn al-Ju'fī}

(Born in 915 C.E.)

Dìwăn (ed. 'U. F. al-Ṭabbā'), language: Arabic; subject: poem in Arabic.

See vol. 1, under jä'a Nawrüzunā, p. 397.

9. al-Azdī, Abū Zakariyyā Yazīd b. Muḥammad b. Iyās b. alQāsim

(Died in 945-6 C.E.) 
Ta'rīkh al-Mawsil (ed. 'A. Habība), language: Arabic; subject: history.

See under wa dakhalat sana tas' wa 'ashrīn wa mā'a, p. 88.

Ibid., cf. under wa dakhalat sana thamān wa arba'īn wa mä'a, p. 208.

10. Abu al-Faraj al-Ișbahānī/al-Ișfahānī, 'Alī b. al-Husayn b. Muhammad b. Aḥmad al-Qurashī

(Lived from 897 to 967 C.E.)

Kitāb al-Aghān $\bar{\imath}$ (ed. Turāth al-'Arabī), language: Arabic; subject: rijāl, literature and music.

See vol. 3, under akhbär Bashshär b. Burd wa nasabuhü, p. 149.

Cf. vol. 19, under akhbār Bakr b. al-Nattāh wa nasabuhü, p. 75.

\section{1. ibn Zakariyyān, Abī Husayn Aḥmad b. Fāris}

(Lived in the tenth century C.E.)

Mu'jam Maqāiyys al-Lugha (ed. 'A. M. Hārūn), language: Arabic; subject: dictionary.

See vol. 5, under bāb al-kāf wa al-rā wa mā yuthallithhumā, p. 176.

\section{Anonymous}

(Ca. tenth century C.E.)

Rasä'il Ikhwān al-Șafā' wa Khillān al-Wafā' (ed. B. al-Bustänī), language: Arabic; subject: miscellaneous.

See vol. 2, under al-jismānīyāt al-tabī' $\bar{\imath} y \bar{a} t / f a s ̦ l$ fì bayān shikāyat alhayawān min..., p. 214.

Ibid., cf. under fașl, p. 370.

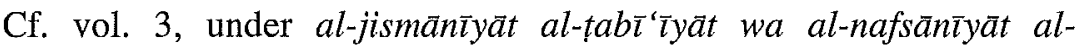
'aqlīyät/fașl, p. 277.

Cf. vol. 4, under al-'ulüm al-nämūsìyya al-ilähìyya wa al-shar'‘̄yya al-dīnīyyalfașl, p. 159.

\section{Hujwīī, Abu al-Hasan 'Alī b. 'Uthmān b. 'Alī al-Ghaznawī} (Died ca. 1072-1077 C.E.)

Kashf al-Mahjüb li-Arbāb al-Qulüb (ed. V. A. Žukovskiy), language:

Persian; subject: sufism.

See under $b \bar{a} b$ al-jū $d$ wa al-sakhāwa, p. 411. 
14. al-Ghazzālī, Abū Ḥāmid Muḥammad b. Muḥammad al-Ṭūsī (Lived from 1058 to 1111 C.E.)

Nașihtat al-Mulük (ed. J. Humāī), language: Persian; subject: ethics.

See under āghäzi shākhihāayi* $\bar{\imath} m \bar{a} n$, p. 360.

\section{Ișțakhrī, Abū Isḥāq Ibrāhīm}

(Lived in the tenth century C.E.)

Tarjumi-yi Färs̄̄-yi Masālik wa Mamālik (ed. I. Afshār), language:

Persian; subject: geography.

See p. 88, p. 127, p. 154, p. 165.

16. Nizāmī Ganjawī, Jamāl al-Dīn Abū Muḥammad Ilyās b. Yūsuf b. Zakī Mu'ayyad

(Born ca. 1141 to before 1146 C.E.)

Khusraw wa Shīrin (ed. H. V. Dastgirdī), language: Persian; subject: love story, poem in Persian.

See under küh kandan-i Farhād wa zärī-yi $\bar{u}$, p. 246.

Ibid., cf. under andarz wa khatm-i kitāb, p. 443.

Idem, Laylä wa Majnūn (ed. H. V. Dastgirdī), language: Persian; subject: love story.

Cf. under yäd-i mādar-i khud Ra'isa-yi Kurd, p. 49.

Idem, Haft Paykar (ed. H. V. Dastgirdī), language: Persian; subject: mathnawi.

See under nishastan-i Bahrām rüz-i Panjshanba dar gunbad-i șandalī, pp. 273-274.

Loc. cit., pp. 277-284.

Loc. cit., pp. 289-290.

Ibid., cf. under andarz giriftan-i Bahrām az shabān, p. 330.

Ibid., cf. under shikäyat kardan-i mazlüm-i shishom, p. 340.

Idem, Sharaf-nāma (ed. H. V. Dastgirdī), language: Persian; subject: mathnawi.

See under ta' līm-i Khiḍr dar guftan-i dāstān/sāqī-nāma, p. 53.

\section{Sharîf al-Idrīsī, $A$ bī 'Abd Allāh}

(Lived in the twelfth century C.E.)

Nuzhat al-Mushtāq fi Ikhtirāq al-Āfäq (ed. 'Ālam al-Kutub), lang- 
uage: Arabic; subject: geography.

See vol. 1, under wa amma..., p. 353.

Cf. vol. 2, under al-juz' al-sädis, p. 821.

18. Anwarī, Awḥad al-Dīn Muḥammad b. Muḥammad Khāwarān̄̄

(Died probably in 1189 or 1191 C.E.)

Dīwān (ed. P. Bābāī), language: Persian; subject: poem in Persian.

See under muqatta'a ät/dar shikāyat-i dahr, pp. 555-556.

Ibid., cf. under shabī dar hāl-i mastī az bāmī dar uftäd ìn qit'a rā guft, p. 559.

\section{Jurfādiqān̄̄, Abu al-Sharaf Nāșịh b. Ẓafar}

(Lived in the twelfth century C.E.)

Tārīkh-i Yamīnī (ed. J. Cheār), language: Persian; subject: history.

See under risīdan-i Hisām al-Dula Abu al-'Abbäs Täsh bi Jurjān, p. 81.

Ibid., cf. under khurüjj-i Muntașir Abū Ibrähīm Ismā'll b. Nüh wa änči...shud, p. 189.

Loc. cit., pp. 197-198.

Ibid., cf. under dhikr-i Shams al-Ma'älī Qābūs b. Wushmgīr wa risīdan-i $\bar{u}$ ba sar-i mamlikat-i khish, p. 227.

Loc. cit., p. 229.

Loc. cit., p. 243.

Ibid., cf. under dhikr-i guzashtan-i İlak Khän az Jiyhūn, p. 283.

Loc. cit., p. 286.

Ibid., cf. under dhikr-i Amīr al-Muminīn al-Qādir bi-Alläh wa...'Add al-Dula, p. 307.

Ibid., cf. under dhikr-i Majd al-Dula b. Fakhr al-Dula, p. 358.

\section{Sa'dī, Abū 'Abd Allāh Musharrif al-Dīn b. Muṣliḥ}

(Died in 1292 C.E.)

Bustān (ed. M. 'A. Furūghī), language: Persian; subject: poem in Persian.

See under hikāyat, p. 318.

Ibid. under hikāyat, p. 331. 
14. al-Ghazzālī, Abū Ḥāmid Muḥammad b. Muḥammad al-Ṭūsī (Lived from 1058 to 1111 C.E.)

Nașīhat al-Mulūk (ed. J. Humāī), language: Persian; subject: ethics.

See under ăghāzi shäkhihā-yi* imān, p. 360.

\section{Ișțakhrī, Abū Isḥāq Ibrāhīm}

(Lived in the tenth century C.E.)

Tarjumi-yi Fārs̄i-yi Masālik wa Mamālik (ed. I. Afshār), language:

Persian; subject: geography.

See p. 88, p. 127, p. 154, p. 165.

16. Nizāmī Ganjaw̄ī, Jamāl al-Dīn Abū Muḥammad Ilyās b. Yūsuf b. Zakī Mu'ayyad

(Born ca. 1141 to before 1146 C.E.)

Khusraw wa Shīrinn (ed. H. V. Dastgirdī), language: Persian; subject: love story, poem in Persian.

See under küh kandan-i Farhäd wa zärī-yi $\bar{u}$, p. 246.

Ibid., cf. under andarz wa khatm-i kitäb, p. 443.

Idem, Laylā wa Majnūn (ed. H. V. Dastgirdī), language: Persian; subject: love story.

Cf. under yād-i mādar-i khud Ra'tsa-yi Kurd, p. 49.

Idem, Haft Paykar (ed. H. V. Dastgirdī), language: Persian; subject: mathnawi.

See under nishastan-i Bahrām rūz-i Panjshanba dar gunbad-i sandalī, pp. 273-274.

Loc. cit., pp. 277-284.

Loc. cit., pp. 289-290.

Ibid., cf. under andarz giriftan-i Bahräm az shabān, p. 330.

Ibid., cf. under shikāyat kardan-i mazlüm-i shishom, p. 340.

Idem, Sharaf-nāma (ed. H. V. Dastgird̄i), language: Persian; subject: mathnawi.

See under ta' '̄ìm-i Khidr dar guftan-i dāstān/sāqū-nāma, p. 53.

\section{Sharīf al-Idrīsī, Abī 'Abd Allāh}

(Lived in the twelfth century C.E.)

Nuzhat al-Mushtāq fi Ikhtirāq al-Āfāq (ed. 'Ālam al-Kutub), lang- 
uage: Arabic; subject: geography.

See vol. 1, under wa ammā..., p. 353.

Cf. vol. 2, under al-juz' al-sädis, p. 821.

18. Anwarī, Awḥad al-Dīn Muḥammad b. Muḥammad Khāwarānī

(Died probably in 1189 or 1191 C.E.)

Dīwān (ed. P. Bābāì), language: Persian; subject: poem in Persian.

See under muqatța'āt/dar shikāyat-i dahr, pp. 555-556.

Ibid., cf. under shabī dar hāl-i mastī az bāmī dar uftād ìn qit'a rā guft, p. 559.

\section{Jurfādiqān̄̄, Abu al-Sharaf Nāṣiḥ b. Ẓafar}

(Lived in the twelfth century C.E.)

Tărīkh-i Yamīñ̄ (ed. J. Cheār), language: Persian; subject: history.

See under risīdan-i Hisām al-Dula Abu al-'Abbās Tāsh bi Jurjān, p. 81.

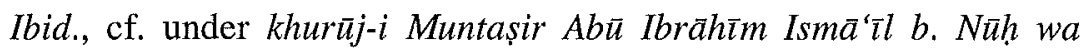
anči...shud, p. 189.

Loc. cit., pp. 197-198.

Ibid., cf. under dhikr-i Shams al-Ma'älī Qābūs b. Wushmgīr wa risīdan-i $\bar{u}$ ba sar-i mamlikat-i khīsh, p. 227.

Loc. cit., p. 229.

Loc. cit., p. 243.

Ibid., cf. under dhikr-i guzashtan-i Illak Khān az Jiyhün, p. 283.

Loc. cit., p. 286.

Ibid., cf. under dhikr-i Amīr al-Muminīn al-Qādir bi-Alläh wa...'Aded al-Dula, p. 307.

Ibid., cf. under dhikr-i Majd al-Dula b. Fakhr al-Dula, p. 358.

\section{Sa'dī, Abū 'Abd Allāh Musharrif al-Dīn b. Muṣliḥ̣}

(Died in 1292 C.E.)

Bustān (ed. M. 'A. Furūghī), language: Persian; subject: poem in Persian.

See under hikāyat, p. 318.

Ibid. under hikāyat, p. 331. 


\section{Kirmānī, Awḥad al-Dīn Ḥāmid b. Abī al-Fakhr}

(Lived in the thirteenth century C.E.)

Manāqib (ed. B. Furūzānfar), language: Persian; subject: Sufism.

See pp. 130-131.

\section{Mawlānā Jalāl al-Dīn Rūmī, b. Bahā' al-Dīn Sulțān al`'Ulamā} Walad b. Husayn b. Aḥmad Khațībĩ

(Died in 1273 C.E.)

Mathnaw̄̄-yi Ma'nawī (ed. R. A. Nicholson), language: Arabic; subject: sufism.

See under daftar-i awwal, kushtan-i wazīr khīshtan rā dar khalwat, p. 75.

Ibid., cf. under dar khāb guftan-i Hätifmar 'Umar..., p. 140.

Ibid., cf. under dar bayān-i ānki häl-i khud wa mastī-yi khud pinhān bāyad dāsht az jāhilän, p. 204.

Cf. under daftar-i duwwum, shikāyat kardan-i ahl-i zindān, pp. 259260.

Cf. under daftar-i siwwum, qișși-yi faryād risìd-i Rasūl 'alayhi alsalām kāriwān-i 'Arab rä..., p. 546.

Cf. under daftar-i čahärum, mathal-i qāni` shudan-i ädamī bi dunyā wa hirș-i $\bar{u} . .$, p. 677.

\section{Abi al-Hayjā', Amīr 'Izz al-Dīn Muhammad}

(Lived in the thirteenth century C.E.)

Ta'rīkh (ed. Ș. 'A. Muhammad), language: Arabic; subject: history.

See under al-sana al-thānīya wa al-sab'ūn wa thalāthmà'a, p. 67.

Cf. under al-sana al-täsi' $a$ wa al-sab'ūn wa thalathmä'a, p. 69.

Cf. under al-sana al-sābi 'a wa al-thamānūn wa thalāthmā'a, p. 76.

Cf. under al-sana al-khämisa wa arba'mā'a, pp. 84-85.

Cf. under al-sana al-tāsi 'a wa al-arba' ūn wa arba'ma'a, p. 104.

Cf. under al-sana al-khamsūn wa arba'mā'a, p. 106.

Cf. under al-sana al-h̄āìya wa al-khamsūn wa arba 'mā'a, p. 110.

Cf. under al-sana al-thāitha wa al-sittūn wa arba'má' $a$, p. 119.

Cf. under al-sana al-sābi 'a wa al-sittūn wa arba' $m \bar{a}$ 'a, p. 123.

Cf. under fașl fĭ wilaya Ban̄̄ Marwän al-Kurd̄̄, p. 148.

Cf. under al-sana al-sādisa wa al-khamsmā'a, p. 170.

Cf. under al-sana al-tāsi 'a wa al-khamsmä'a, p. 173. 
Cf. under al-sana al-säbi' a wa al-thaläthūn wa khamsmā'a, p. 203. Cf. under al-sana al-tāsi 'a wa al-thalāthūn wa khamsmā'a, p. 207.

Cf. under al-sana al-thānìya wa al-arba' 'ūn wa khamsmā'a, p. 210.

Cf. under al-sana al-rābi 'a wa al-arba'ūn wa khamsmā'a, p. 214.

Cf. under al-sana al-thāmina wa al-arba'ūn wa khamsmä'a, p. 228.

24. ibn al-Mustūfĩ, Sharaf al-Dīn Abi al-Barakāt Mubārak b. Aḥmad al-Najmī al-Arbilī

(Lived in the thirteenth century C.E.)

Ta'rikh Arbil (ed. S. S. Kh. al-Șaqār), language: Arabic; subject: history and rijal.

See vol. 1, under Abu al-Faraj al-Wāsițī, p. 140.

Ibid., cf. under al-Qädī al-Mahāñ̄*, p. 159.

Ibid., cf. under Abü 'Alī b. Khall, p. 172.

25. al-Nasawī, Shihāb al-Dīn Muhammad b. Aḥmad b. 'Alī b. Muhammad al-Khurandiz̄ al-Zaydarī

(Died in 1249-50 C.E.)

Sìrat-i Jalāl al-Dīn Minakbarn̄̄ (ed. M. Mīnuwī), language: Persian; subject: history.

See under dhikr-i 'āqibat-i Sultān Jalāl al-Dīn Minakbarnī, p. 279.

26. ibn Manẓūr, Muḥammad b. Mukarram b. 'Alī b. Aḥmad alAnșārī al-Ifrìqī al-Miṣrī Jamāl al-Dīn Abu al-Faḍl

(Lived from 1233 to $1311-1312$ C.E.)

Lisān al-'Arab (ed. M. 'Abd al-Wahhāb and M. Ș. al-'Abīdī), language: Arabic;, subject: dictionary.

See vol. 1, under $i b r \bar{\imath} z$, p. 374.

Ibid., cf. under al-bazarī, p. 398.

Ibid., cf. under ban̄, p. 511.

Ibid., cf. under bahiya, p. 528. 
27. ibn Khaldūn, Walī al-Dīn 'Abd al-Raḥmān b. Muḥammad b. Muhammad b. Abī Bakr Muḥammad b. al-Ḥasan

(Born in 1332 C.E.)

Muqaddima (ed. Maktaba al-Hilāl), language: Arabic; subject: sociology.

See under iqlīm al-thālith, p. 49.

Ibid., cf. under al-faṣl al-thān̄, p. 84.

Ibid., cf. under al-faṣl al-häd̄̄ wa al-'ashrūn, p. 100.

Ibid., cf. under al-fașl al-sābi' wa al-thaläthün/fi al-hurüb wa madhāhib al-umam wa tartībuhā, p. 175.

\section{Qāọī Khān, Badr Muhammad Dahār}

(Lived in the late thirteenth and early fourteenth centuries C.E.)

Dastūr al-Ikhwān (ed. S. Najafī Asadullāhī), language: Persian; subject: dictionary

See vol. 1, under al-Kurd wa al-kurda, p. 517.

\section{9. al-Hāfiz al-Mizzay, Abu al-Hujjāj Yūsuf b. 'Abd al-Raḥmān} b. Yūsuf al-Qāọī al-Kalbī al-Dimashqī

(Lived in the late thirteenth and early fourteenth centuries C.E.)

Tahdhīb al-Kamāl fi Asmä' al-Rijāl (ed. A. 'A. 'Ubayd and H. A. Āghā), language: Arabic; subject: rijāl.

See vol. 3, under Jäbir b. Kurd̄̄ b. Jäbir al-Wāsit̄̄,Abu al-'Abbās alBazzār, p. 300.

Cf. vol. 5, under Khälid b. Dīnār al-Tamīmī al-Sa'dī, Abu al-Khalda al-Bașrì al-Khayyät, p. 345.

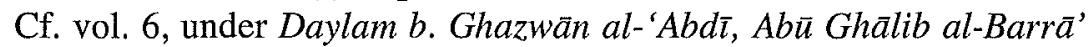
al-Bașrī, p. 75.

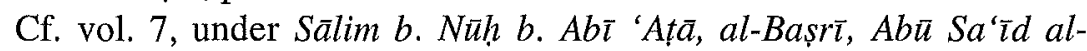
'Atțār, p. 31.

Ibid., cf. under Sa'ìd b. Yahyā b. Mahdī b. 'Abd al-Rahmān b. 'Abd Kaläl*, Abü Sufyān al-Himayrī, p. 325.

Cf. vol. 15, under al-Fadl b. 'Amiyra al-Qaysī al-Tafāwī, Abū Qutayba al-Bașrī, p. 83.

Cf. vol. 18, under $b \bar{a} b$ al-mīm, p. 69.

Ibid., cf. under Maymūn al-Kurd̄, p. 560. 
Cf. vol. 20, under $b \bar{a} b a l-y \bar{a}^{\prime}$, p. 93.

30. ibn Kathīr, 'Imād al-Dīn Ismā̄īl b. 'Umar b. Kathīr

(Died in 1373 C.E.)

al-Bidāya wa al-Nihāya (ed. 'A. Handāwī), language: Arabic; subject:

History and rijal.

See vol. 1, under qișsa Ibrähìm, p. 168.

See vol. 6 , under min sana ihdi wa thamānīn ila sana tas'in min alhijra al-nabawitya, p. 421.

See vol. 7, under min sana ihd $\bar{\imath}$ wa khamsayn wa mä'a ilä sana sittīn wa mä'a min al-hijra al-nabawĩya, p. 179.

Ibid., cf. under wa qal Ja'far b. Muhammad al-Sa'igh, p. 369.

See vol, 8, under thumma dakhalat sana sitt wa 'ashrin wa thaläth$m \bar{a}^{\prime} a$, p. 43.

Ibid., cf. under thumma dakhalat sana thamän wa thamänīn wa thalathma'a, p. 183.

Ibid., cf. under thumma dakhalat sana ihdī wa 'ashrīn wa arba'mā'a, p. 239.

Ibid., cf. under thumma dakhalat sana tas' wa thaläthīn wa arba'$m \bar{a}^{\prime} a$, p. 266.

Ibid., cf. under thumma dakhalat sana thamān wa khamsīn wa khamsma'a, p. 449.

Ibid., cf. under qäl al-'Imäd al-Kätib, p. 472.

Ibid., cf. under thumma dakhalat sana thaläth wa tas'inn wa khams$m \bar{a}^{\prime} a$, p. 565.

See vol. 9, under waqa'a 'Ayn Jālüt, p. 161.

Ibid., cf. under dhikr maqtal al-Jashankīr, p. 334.

Ibid., cf. under thumma dakhalat sana thalāthīn wa sab 'mā'a, p. 418.

Ibid., cf. under thumma dakhalat sana ihdī wa thaläthīn wa sab 'mā'a, p. 420.

31. ibn al-Wardī, Zayn al-Dīn Abū Ḥafṣ 'Umar b. Muẓaffar b. 'Umar b. Abi al-Fawāris Muhammad b. 'Alī al-Wardī alQurashī al-Bakrī al-Shāfi'ī

(Died in 1349 C.E.)

Ta'rīkh ibn al-Wardī (ed. M. M. H. al-Khursān), language: Arabic; subject: history. 
See vol. 1, under akhbār al-Mutī’ b. al-Muqtadir, p. 392.

Loc. cit., cf. p. 409.

Ibid., cf. under akhbär al-Tā'i'Alläh, p. 422.

Ibid., cf. under ta'rīkh 'amāra, p. 516.

See vol. 2, under akhbär al-bātin̄̄ya, p. 20.

Ibid., cf. under maqtal al-Räshid, p. 62.

Ibid., cf. under akhbār Bañ̄ Munqadh wa al-zaläzil, p. 81.

Ibid., cf. under dhikr masīr Sulaymān Shäh ilā Hamadān wa qatlihū, p. 91.

Loc. cit., cf. p. 101.

Ibid., cf. under Shīr Kuh wa Ayyūb, p. 108.

Ibid., cf. under dhikr wafät al-Malik al-'Ādil, p. 195.

Loc. cit., cf. p. 199.

Ibid., cf. under talkhīs min ta'rīkh Jaläl al-Dīn, p. 225.

Ibid., cf. under istīlä' al-'Azīz b. al-Zähir 'alä Shīzar, p. 252.

Ibid., cf. under qașd Hulākū al-Shäm, p. 291.

Ibid., cf. under qabad al-Malik al-Sa' $\mathrm{l} d$ wa' 'ùd al-Tatar, pp. 314-315.

Loc. cit., cf. p. 322.

Loc. cit., cf. p. 325.

Ibid., cf. under qudūm Qabjaq ilā Hamāh, p. 406.

Loc. cit., cf. p. 494.

32. Rashīd al-Dīn Faḍl Allāh/Ṭabīb, b.'Imād al-Dawla Abu alKhayr

(Lived ca. $1247-1318$ C.E.)

Jāmi al-Tawārīkh (ed. B. Karīmī), language: Persian; subject: history.

See vol. 1, under tārikh-i Mulük wa Atābakān, p. 262.

Ibid., cf. under tärīkh-i Salāțīn, p. 608.

See vol. 2, under dästān-i Sultān Alımad, p. 784.

Ibid., cf. under hilkäyat-i raftan-i lashgar bi daf'-i Kurdān-i Küh-i Hakkār wa ..., p. 812.

Ibid., cf. under hikāyat-i wușül-i Qutlughshāh-i Nuyān bi lashgar-i Mișr wa murāji at nimūdan az ānjä wa ..., p. 956.

Ibid., cf. under hikāyat-i nūzdahum dar daf'-i duzdān wa rāhzanān wa muhāfizat-i rāh-hā az $\bar{\imath}$ shān, p. 1051. 
33. al-Qāshān̄̄, Abu al-Qāsim 'Abd Allāh b. Muḥammad (Lived in the fourteenth century C.E.)

Tārīkh-i Uljāytu (ed. M. Hambly), language: Persian; subject: history. See under waqāyi' ${ }^{-}-i$ s $\bar{a} l-i$ 706, p. 66.

Ibid., cf. under waqayyi $-i$ săl-i 707, p. 76.

Ibid., cf. under waqāyi ${ }^{-}-i$ săl-i 712, p. 143.

Ibid., cf. under waqayi ${ }^{-}-i$ săl-i 715 , p. 198.

\section{4. al-Fīrūzābādī, Majd al-Dīn Muhammad Ya'qūb}

(Lived in the late fourteenth and early fifteenth centuries C.E.)

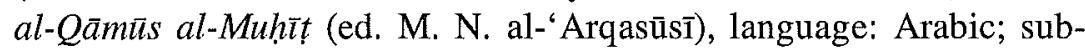
ject: dictionary.

See under al-kard ... Akrād, wa jadduhum Kurd b ...., p. 315.

35. al-Damīrī, Muḥammad b. Mūsā b.'Ī̄ā Kamāl al-Dīn

(Born around the beginning of the year 1341 or 1344 C.E.)

Hayāt al-Hayawān al-Kubrā (ed. 'A. Sāmirbītīya), language: Arabic; subject: veterinary science and literature.

See vol. 1, under tadhn̄̄b/Abū Muslim al-Khuräsān̄̄, p. 10.

Ibid., cf. under al-hajal, p. 219.

\section{Jāmī, Mawlānā Nūr al-Dīn 'Abd al-Raḥmān}

(Died in 1492 C.E.)

Nafahāt al-Uns (ed. M. 'Äbidī), language: Persian; subject: hagiography.

See under Shāh Shujā'-i Kirmän̄̄, p. 84.

Ibid., cf. under Abū 'Abd Alläh al-Mushtahir Babābawt, p. 325.

Ibid., cf. under Qudayb al-Bän Mawșili, p. 525.

Ibid., cf. under Sheikh Jākīr, p. 537.

Ibid., cf. under Kurdīyya, p. 616.

37. ibn 'Arabshāh, Aḥmad b. Muḥammad b. 'Abd Allāh b. Ibrāhīm Shihāb al-Dīn Abu al-.'Abbās al-Dimashqī al-Ḥanafī al'Ajamī

(Died in 1450 C.E.)

'Ajā'ib al-Maqdūr fi Nawā'ib Taymūr (ed. A. F. al-Hamșī), language: 
Arabic; subject: history.

See under dhikr tarkihu fï al-muhāșira...ilä Baghdād, p. 300.

\section{Shāmī, Nizām al-Dīn}

(Lived in the late fourteenth to early fifteenth centuries C.E.)

Zafar-näma (ed. F. Tower), language: Persian; subject: history.

See under dhikr-i tawajjuh-i Amīr-i Șăhibqirān, p. 99.

Loc. cit., cf. p. 104.

Cf. under dhikr-i qishlāq kardan-i Amīr-i Șāhibqirān dar Māzandarān wa ... Shitraz, pp. 129-130.

Cf. under dhikr-i tawajjuh-i Amīr-i Șāhibqirān bi jānib-i Baghdād, p. 141.

Cf. under dhikr-i wăqi'i-yi am̄̄rzädi 'Umar Sheikh Bahädur ..., p. 152.

Cf. under dhikr-i bazgashtan-i Amīr-i Șāhibqirān az Baghdād wa tawajjuh bi jānib-i Tabriz, p. 242.

Cf. under dhikr-i qishlāq farmüdan-i Amīr-i Șăhibqirān dar Qarābägh, p. 245.

Cf. under dhikr-i tawajjuh-i bandiḡ-yi Hadrat bi jānib-i Gurjistān wa ..., p. 278.

\section{9. ibn al-Shiḥna, Muhibb al-Dīn Abu al-Faḍl Muḥammad}

(Died in 1485 C.E.)

al-Durr al-Muntakhab li-Ta'rīkh Halab (ed. K. Ohta), language: Ara-

bic; subject: history.

See under al-bāb al-tāsi'/masjid al-jāmi', p. 59.

Cf. under al-bāb al-tāsi' al-'ashar, p. 191.

Cf. under al-bāb al-thān̄ wa al-'ashrūn, p. 239.

Cf. under al-bāb al-khāmis wa al-'ashrün, p. 254.

\section{Qazwīn̄̄, Būdāq Munshī}

(Lived in the sixteenth century C.E.)

Jawāhir al-Akhbār (ed. M. Bahrāmnižād), language: Persian; subject: history.

See under bāqī-yi ahwāl-i Bāysunqur Mìrzā wa Șüfí Khalīl wa ..., p.

91. 
Cf. under maktūb-i Shāh-i Dīnpanāh bi Wālī-yi Rūm, p. 175.

Cf. under āmadan-i Alqās-i nāsipās bi 'Irāq, p. 202.

Cf. under raftan-i Nawwāa-i kāmyāb bi yiylāq-i Jaqatū wa Naqatū wa. giriftārì-yi Alqās, p. 204.

Cf. under khāb dīdan-i Shāh-i Dīnpanāh, p. 207.

\section{Bibliography of Arabic and Persian Sources}

[The aim of the bibliography is not of course to minimize the sources. All the quoted sources are available. The descriptions given are brief and apply in particular to this study.]

Abi al-Hayjā, Amīr 'Izz al-Dīn, Ta'rīkh, ed. Ș. 'A. Muhammad, Cairo, 1993.

Abu al-Faraj al-Ișbahānī/al-Ișfahānī, 'Alī b. al-Ḥusayn, Kitāb alAghān̄, ed. Turāth al-'Arabī, 24 vols., Beirut, 1994.

al-Andalusī, Ahmad b. Muhammad, al-'Iqd al-Farīd, ed. Taḥqīq alTurāth, 7 vols., Beirut, 1999.

Anonymous, Rasā'il Ikhwān al-Safä' wa Khillān al-Wafä', ed. B. alBustānī, 4 vols., Beirut, 1992.

Anwarī, Awhà al-Dīn Muhammad, Dīwān, ed. P. Bābāī, Tehran, 1997.

ibn 'Arabshāh, Aḥmad b. Muhammad, 'Ajā'ib al-Maqdūr fi Nawā'ib Taymūr, ed. A. F. al-Hamșī, Beirut, 1986.

al-Azdī, Abū Zakariyyā, Ta'rīkh al-Mawșil, ed, 'A. Habība, Cairo, 1967.

al-Balādhurī, Aḥmad b. Yahȳā, Futūh al-Buldān, ed. Taḥqīq alTurāth, Beirut, 1988.

Bashshār b. Burd, Abū Mu'ādh, Dīwān, ed. S. al-Hawwārī, 4 vols., Beirut, 2002.

al-Damīrī, Muhammad b. Mūsā, Hayāt al-Hayawān al-Kubrā, ed. 'A. Sāmirbītĩya, 2 vols., Beirut, 1999.

al-Farāhīdī, 'Abd al-Rạ̣mān, Kitāb al-'Ayn, ed. M. al-Makhzūmī and I. al-Sämarrāị, 9 vols., Qum, 1989.

al-Fīrūzābāđī, Majd al-Dīn, al-Qāmūs al-Muhntt, ed. M. N. al-'Arqasūsī, Beirut, 2003. 
al-Ghazzālī, Abū Hāmid, Naṣịhat al-Mulūk, ed. J. Humāī, Tehran, 1982 .

al-Hāfiz al-Mizzay, Abu al-Hujjāj, Tahdhīb al-Kamāl fĩ Asmä’ alRijāl, ed. A. 'A. 'Ubayd and H. A. Āghā, 24 vols., Beirut, 2000.

Hujwīī, Abu al-Hasan, Kashf al-Mahjüb li-Arbāb al-Qulūb, ed. V. A. Žukovskiy, Leningrad, 1926.

Ișțakhrī, Abū Ishāāq, Tarjumi-yi Fārsī-yi Masälik wa Mamālik, ed. I. Afshār, Tehran, 1968.

al-Jāḥiz, Abū 'Uthmān, Kitāb al-Hayawān, ed. 'A. M. Hārūn, 7 vols., Beirut, 1969.

-al-Bayān wa al-Tabȳ̄n, ed. 'A. Būmulham, 3 vols., Beirut, 2002.

-al-Bukhalä', ed. 'A. 'Abd al-Sātir, Beirut, 2003.

-Kitāb al-Bighāl, ed. 'A. Būmulham, Beirut, 1999.

Jāmī, Mawlānā, Nūr al-Dīn, Nafahăt al-Uns, ed. M. 'Ābidī, Tehran, 1996.

Jurfādiqān̄̄, Abu al-Sharaf, Tārīkh-i Yamīn̄i, ed. J. Cheār, Tehran, 1978.

ibn Khaldūn, Walī al-Dīn 'Abd al-Raḥmān, Muqaddima, ed. Maktaba al-Hilāl, Beirut, 2000.

ibn Kathīr, 'Imād al-Dīn Ismā'īl, al-Bidāya wa al-Nihāya, ed. 'A. Handāwī, 10 vols., Șaydā-Beirut, 2005.

Kirmānī, Awhad al-Dīn, Manāqib, ed. B. Furūzānfar, Tehran, 1969.

ibn Manz̄ūr, Muhammad b. Mukarram, Lisān al-'Arab, ed. M. 'Abd al-Wahhāb and M. Ș. al-'Abīd̄̄, 18 vols., Beirut, 1986.

Mas'ūj̄̄, Abu al-Hasan, Murūj al-Dhahab wa Ma'ädin al-Jawhar $f \mathfrak{i}$ Tuhaf al-Ashräf min al-Mulük wa Ahl al-Dirāyät, ed. Q. al-

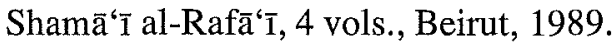

-al-Tanbīh wa al-Ishrāf, ed. Taḥīq al-Turäth, Beirut, 2000.

Mawlāna Jalāl al-Dīn Rūmī, Mathnawī-yi Ma'nawī, ed. R. A. Nicholson, reprint, Tehran, 1996.

ibn al-Mustūfī, Sharaf al-Dīn Abi al-Barakāt, Ta'rīkh Arbil, ed. S. S. Kh. al- Șaqār, 2 vols., [Baghdad], 1980.

al-Mutanabbī, Abu al-Țyyib, $D \bar{\imath} w \bar{a} n$, ed. 'U. F. al-Ṭabbā', 2 vols., Beirut, 1997.

al-Nasawī, Shihāb al-Dīn Muhammad, Sìrat-i Jalāl al-Dīn Minakbarnī, ed. M. Mīnuwī, Tehran, 1965.

Niẓāmī Ganjawī, Jamāl al-Dīn Abū Muḥammad, Khusraw wa Shīrīn, ed. H. V. Dastgirdī, Tehran, 2004 . 
—Laylä wa Majnūn, ed. H. V. Dastgirdī, Tehran, 1934.

- Haft Paykar, ed. H. V. Dastgirdi, Tehran, 2001.

- Sharaf-näma, ed. H. V. Dastgirdī, Tehran, 2002.

Qāḍ̄ Khān, Badr Muhammad, Dastūr al-Ikhwän, ed. S. Najafī Asadullāhī, Tehran, 1970.

al-Qāshān̄i, Abu al-Qāsim 'Abd Allāh, Tārīkh-i Uljāytu, ed. M. Hambly, Tehran, 1969.

Qazwīnī, Būdāq Munshī, Jawāhir al-Akhbār, ed. M. Bahrāmnižăd, Tehran, 2000.

Rashīd al-Dīn Faḍl Allāh/Ṭabīb, Jāmi ‘ al-Tawārīkh, ed. B. Karīmī, 2 vols., Tehran, 1995.

Sa'dī, Abū 'Abd Allāh, Bustān, ed. M. 'A. Furūgh̄̄, Tehran, 1999.

Shāmī, Niz̄ām al-Dīn, Zafar-nāma, ed. F. Tower, Prague, 1937.

Sharīf al-Idrīsī, Abī 'Abd Allāh, Nuzhat al-Mushtāq fi Ikhtirāq al$\bar{A} f a \bar{q} q$, ed. 'Ālam al-Kutub, 2 vols., Beirut, 1989.

ibn al-Shihnna, Muhibb al-Dīn, al-Durr al-Muntakhab li-Ta'rīkh Halab, ed. K. Ohta, Tokyo, 1990.

al-Ṭabarī, Abū Ja ‘far Muhammad, Mukhtașar Ta'rīkh al-Rusul wa alMulūk wa al-Khulafā', ed. N. al-Jarrāh, 6 vols., Beirut, 2003.

ibn al-Wardī, Zayn al-Dīn Abū Hafș 'Umar, Ta'rīkh ibn al-Wardī, ed. M. M. H. al-Khursān, 2 vols., Nadjaf, 1969.

ibn Zakariyyān, Abī Husayn Ạ̣mad b. Fāris, Mu'jam Maqaaiyys alLugha, ed. 'A. M. Hărūn, Cairo, 1948. 